\title{
ANALISIS PENGARUH KEBIJAKAN PEMERINTAH DAN MODAL SOSIAL TERHADAP KINERJA SOSIAL EKONOMI LEMBAGA PERKREDITAN DESA DAN KESEJAHTERAAN RUMAH TANGGA MISKIN DI KECAMATAN MENGWI KABUPATEN BADUNG
}

\author{
Gede Putu Surya Wisudayana ${ }^{1}$ \\ I Wayan Sudirman ${ }^{2}$ \\ I Gede Sudjana Budiasa ${ }^{3}$
}

\author{
${ }^{1,2,3}$ Fakultas Ekonomi dan Bisnis Universitas Udayana (Unud), Bali, Indonesia \\ Email : suryawisudayana@gmail.com
}

\begin{abstract}
ABSTRAK
Studi tentang lembaga keuangan mikro sebagai lembaga keuangan yang berfungsi sebagai pendamping rumah tangga miskin untuk menjadi lebih sejahtera dan keluar dari lingkaran kemiskinan dapat dilakukan melalui intitusi keuangan yang berhasil mengurangi jumlah rumah tangga miskin (Devaraja, 2011). Laporan Hong et al. (2007) untuk praktek pengembangan Lembaga keuangan mikro di Vietnam membuktikan dapat menurunkannya jumlah rumah tangga miskin di pedesaan. Di Indonesia, keberadaan lembaga keuangan mikro telah memberikan kontribusi yang sangat nyata bagi akses keuangan rumah tangga miskin, tetapi masih terkendala oleh terbatasnya kontribusi Lembaga keuangan mikro Indonesia hanya sebesar 1.63 persen ( Siregar, 2016). Strategi pengembangan lembaga keuangan mikro digambarkan oleh Porter and Kramer, (2011) sebagai strategi target base of pyramid dan target shared value yang menunjukkan perlunya lembaga keuangan mikro membangun kekuatan usaha untuk mencapai laba secara berkesimbungan serta perluasan akses keuangan kepada rumah tangga miskin..
\end{abstract}

Kata Kunci : kebijakan pemerintah, modal sosial, lembaga perkreditan desa dan kesejahtraan rumah tangga miskin

\begin{abstract}
Study of the micro finance institution as a financial institution that serves as a companion to the poor households to become more prosperous and out of the circle of poverty can be made through a financial institution that manages to reduce the amount of poor households (Devaraja, 2011). Report Hong et al (2007) for the practice of the development of microfinance institutions in Viet Nam proves it can overthrow the number of poor households in rural. In Indonesia, the existence of micro finance institutions have contributed a very real financial access for poor households, but it is still constrained by the limited contribution of microfinance institutions Indonesia only amounted to 1.63 per cent (Siregar, 2016). The strategy of the development of microfinance institutions was described by Porter and Kramer, 2011 as the target strategy base of pyramid and the target shared value that indicates the need for microfinance institutions to build the strength of the attempt to reach the profit in berkesimbungan as well as the expansion of financial access to poor households. Goal you want to accomplish this research is to analyze the effect of social capital, Government policy and socio-economic performance of microfinance institutions against the welfare of the community.
\end{abstract}

Keywords: Government policy, social capital, Lembaga Perkreditan Desa ( LPD) and Poor households 


\section{PENDAHULUAN}

Keberadaan lembaga keuangan sebagai pendukung laju pertumbuhan ekonomi telah banyak dikemukakan dalam berbagai studi sejak tahun 1970-an. Beck et al. (2007) menyajikan studi empiris berkaitan dengan kemudahan akses dari lembaga keuangan mikro pada rumah tangga berpendapatan rendah dan telah berhasil membangun kesejahteraan kelompok berpendapatan rendah tersebut. Laporan Bank Dunia (2014) menyajikan hasil survei yang menunjukkan bahwa kehadiran lembaga keuangan mikro telah membantu mempercepat inklusi keuangan yang berfungsi mengurangi jumlah penduduk miskin.

Lembaga keuangan mikro merupakan lembaga keuangan yang diposisikan sebagai lapis kedua, yang berbeda dengan lembaga keuangan lapis pertama yaitu bank komersial yang memiliki tujuan tunggal melaksanakan fungsi intermediasi keuangan dengan orientasi laba. Sedangkan pada lembaga keuangan mikro yang disebut sebagai lapisan kedua dari lembaga keuangan, yaitu melaksanakan fungsi intermediasi keuangan dengan dua sasaran, pertama orientasi ekonomi untuk mendapatkan laba, kedua adalah orientasi sosial dengan upaya mensejahterakan kelompok miskin berpendapatan rendah untuk mendapatkan akses pelayanan keuangan (Siregar, 2014).

Di Indonesia, keberadaan lembaga keuangan mikro telah memberikan kontribusi yang sangat nyata bagi akses keuangan rumah tangga miskin, tetapi masih terkendala oleh kontribusi dari lembaga keuangan mikro di Indonesia hanya sebesar 1.63 persen (Siregar, 2016). Pada klasifikasi bank pedesaan, keberadaan lembaga keuangan mikro diatur melalui lembaga keuangan bank dan lembaga 
keuangan bukan bank. Dinyatakan sebagai lembaga keuangan bank antara lain bank pedesaan termasuk BPR, Badan Kredit Desa (BKD), serta lembaga keuangan mikro Bank BRI. Sedangkan lembaga keuangan bukan bank mencakup Lembaga Perkreditan Desa (LPD), Koperasi Simpan Pinjam serta Lembaga Keuangan Mikro (LKM).

Lembaga keuangan bukan bank berfungsi untuk melayani rumah tangga miskin yang tidak mendapatkan akses keuangan dari lembaga keuangan bank. Dengan demikian, lembaga keuangan mikro termasuk LPD dapat berfungsi sebagai lembaga keuangan yang lebih berorientasi kepada fungsi pelayanan sosial kemasyarakatan. Lembaga keuangan mikro dapat menjadi alternatif sebagai penyedia layanan kuangan pada rumah tangga miskin yang tidak dapat membuka akses keuangan pada lembaga keungan bank. Dengan demikian, maka Lembaga Perkreditan Desa (LPD) di Bali adalah berfungsi sebagai lembaga strategis dalam membantu mengurangi jumlah rumah tangga miskin, melalui bantuan akses layanan keuangan LPD.

Keberadaan lembaga keuangan mikro secara teoritik dapat berbeda dengan praktek pengembangannya. Laporan dari ASIAN Development Bank (ADB, 2003) menujukkan terjadinya komersialisasi lembaga keuangan mikro di Indonesia, sehingga tidak berfungsi sebagaimana seharusnya dalam rangka menyediakan akses keuangan kepada warga pedesaan yang tidak tersentuh oleh pelayanan lembaga keuangan bank. Kajian dari ASIAN Development Bank (ADB, 2003) menyatakan adanya empat komponen yang telah membelokkan arah fungsi lembaga keuangan mikro bukan bank di Indonesia menjadi lembaga komersialisi 
yang menyimpang dari fungsi keberadaannya sebagai lembaga keuangan mikro yang berfungsi ganda yaitu sosial dan ekonomi. Penyimpangan lembaga keuangan mikro di Indonesia mencakup empat komponen yaitu, (1) praktek pengembangan produk perbankan yang berorientasi kepada produk bank komersial dengan aneka produk insentif suku bunga. (2) Pengembangan produk perbankan dengan orientasi efisiensi biaya untuk mencapai laba optimal. (3) Mempergunakan pinjaman dana dari bank devisa sebagai sumber pembiayaan kredit kepada masyarakat pengguna. (4) Melaksanakan kegiatan perbankan seperti dipraktekkan pada lembaga keuangan formal yang sangat ketat dalam memperhatikan jaminan kredit, evaluasi kelayakan nasabah serta kelayakan penggunaan sumber dana untuk investasi.

Studi tentang keberadaan Lembaga Perkreditan Desa (LPD) tidak dimaksudkan dalam rangka mendapatkan bantuan subsidi dari pemerintah dan lembaga internasional dalam upaya penguatan struktur permodalan LPD, melainkan adalah upaya untuk mengkaji dan mendapatkan solusi atas layanan Lembaga Perkreditan Desa (LPD) terhadap akses keuangan rumah tangga miskin melalui pola redistribusi dari laba LPD yang didapatkan untuk dialihkan menjadi fungsi sosial dalam rangka mengurangi jumlah rumah tangga miskin, sehingga peranan pemerintah yang diharapkan mencakup sejumlah komponen kebijakan sebagaimana direkomendasikan oleh North (1990), yaitu kebijakan pemerintah yang berkaitan dengan pemberdayaan, pendampingan dan bantuan pengembangan kemitraan usaha. 
Kebijakan pemerintah dalam rangka menurunkan rumah tangga miskin telah banyak dilaksanakan secara langsung melalui program bedah rumah, bantuan beras serta bantuan keuangan. Defourny and Nyssens (2010) yang memandang bantuan dana menjadi bagian startegis dalam rangka pengembangan dan penguatan sumber permodalan LPD tidak menjadi fokus pilihan strategis penelitian ini, karena terbukti secara empiris bahwa ketergantungan lembaga keuangan mikro terhadap donasi serta tidak terdapat bukti yang signifikan atas bantuan donasi untuk dialirkan menjadi bantuan peningkatan akses pelayanan keuangan kepada rumah tangga miskin (Reed, 2015), dapat disimpulkan sebagai pilihan strategi yang tidak menjadikan lembaga lembaga keuangan mikro menjadi berkelanjutan dimasa depan.

Konsep modal sosial yang digagas oleh Putnam (1993) meliputi komponen kepercayaan, jaringan dan norma telah dijadikan sebagai instrumen untuk mengurangi rumah tangga miskin, antara lain melalui pemberdayaan yang dilakukan oleh Bank Dunia (1990) di Indonesia dan sejumlah negara lainnya. Kajian Cécile et al., (2010) membuktikan bahwa peran modal sosial memberikan konstribusi yang signifikan dalam mengurangi jumlah rumah tanggai miskin di pedesaan India.

Peran modal sosial sebagai kekuatan dalam membangun persepsi kebersamaan pada rumah tangga miskin dapat dilihat dari tiga aspek yaitu (a) adanya kerja sama dalam penguatan jaringan mendapatkan informasi peluang kerja, informasi pendidikan, kesehatan dan sejumlah aspek penting lainnya. (b) modal sosial dapat berfungsi dalam menggerakkan kebersamaan membangun 
keterampilan, penguatan akses keuangan dan permodalan secara lebih mandiri, serta membangun kekuatan pasar kerja bersama. (c) bahwa modal sosial dapat menjadi kekuatan dalam membangun kemandirian ekonomi melalui tindakan kolektif dalam membangun rumah tinggal yang lebih sehat, sanitasi lingkungan dan gerakan mewujudkan hidup sehat lainnya Cécile et al. (2010).

Kaplan dan Norton (1992) menyatakan bahwa pengukuran kinerja organisasi dapat dilakukan melalui penggabungan aspek pengukuran kinerja keuangan dan non keuangan. Aspek kinerja berdasarkan Kaplan dan Norton (1991) mencakup antara lain (a) aspek perspektif keuangan, (b) aspek perspektif pelanggan, (c) aspek biaya internal serta (d) aspek pembelajaran pertumbuhan usaha. Sehubungan dengan pertimbangan bahwa lembaga keuangan lembaga keuangan mikro juga memiliki peran ganda sebagai lembaga lembaga keuangan mikro yang memiliki target sosial, maka pengukuran kinerja dapat dilakukan melalui penggabungan antara target pencapai laba usaha melalui pendekatan balanced scorecard (Kaplan dan Norton, 1991) serta target mencapai tujuan sosial (Kipesha, 2013). Dengan demikian, kinerja lembaga keuangan lembaga keuangan mikro dinyatakan berhasil mencapai target kinerja apabila dapat memenuhi keduanya, yaitu target capaian kinerja ekonomi (Kaplan dan Norton, 1991) serta target capaian kinerja sosial (Kipesha, 2013). 
Tabel 1

PDRB dan Rumah Tangga Miskin Kabupaten / Kota di Propinsi Bali Tahun 2014

\begin{tabular}{clcr}
\hline No. & Kabupaten/Kota & $\begin{array}{c}\text { Rumah Tangga Miskin } \\
(\%)\end{array}$ & \multicolumn{2}{c}{$\begin{array}{c}\text { PDRB } \\
\text { (Milyaran Rupiah) }\end{array}$} \\
\hline 1 & Jembrana & 5.83 & $7,134.66$ \\
2 & Tabanan & 5.61 & $11,904.19$ \\
3 & Badung & 2.54 & $27,456.37$ \\
4 & Gianyar & 4.57 & $14,272.75$ \\
5 & Klungkung & 7.01 & $4,536.26$ \\
6 & Bangli & 5.86 & $3,472.22$ \\
7 & Karangasem & 7.3 & $8,482.88$ \\
8 & Buleleng & 6.79 & $17,740.83$ \\
9 & Denpasar & 2.21 & $26,777.48$ \\
\hline Sumber: BPS Propinsi Bali & &
\end{tabular}

Berdasarkan data pada Tabel 1 dapat dilihat bahwa persentase rumah tangga miskin di Kabupaten Badung menempati urutan ke dua terendah di Propinsi Bali yaitu sebesar 2,54 persen setelah Kota Denpasar yang sebanyak 2,21 persen, namun jika dilihat dari besarnya PDRB antar Kabupaten/Kota maka Kabupaten Badung memikili PDRB terbesar di Propinsi Bali sebesar 27.456,37 milyar rupiah kemudian diikuti oleh Kota Denpasar sebanyak 26.777,48 milyar rupiah, Hal ini menunjukan bahwa masih terdapat kemungkinan untuk menurunkan jumlah rumah tangga miskin di Kabupaten Badung.

Tabel 1.2 menyajikan kondisi rumah tangga miskin dan anak-anak putus sekolah di wilayah Badung Selatan yang masih menunjukkan relative tinggi. Hal yang juga tidak berbeda jauh dari beberapa wilayah kecamatan di Badung Utara (Tabel 1.2). Berdasarkan kajian empirik yang telah disampaikan sebelumnya, serta fakta dukungan fenomena rumah tangga miskin di wilayah Kabupaten Badung, maka penelitian ini berusaha mengkaitkan LPD sebagai lembaga 
keuangan mikro sebagai instrumen akses keuangan rumah tangga miskin, dipadukan dengan penguatan kebijakan pemerintah terhadap pemberdayaan rumah tangga miskin secara langsung maupun melalui penguatan modal sosial, diharapkan dapat dicapai penurunan rumah tangga miskin di Kabupaten Badung.

Tabel 2

Jumlah Siswa Putus Sekolah dan Rumah Tangga Miskin Badung Selatan

\begin{tabular}{clcc}
\hline No. & Kecamatan & Putus Sekolah & Rumah Tangga Miskin \\
\hline 1 & Kuta Selatan & 47 siswa & $401 \mathrm{kk}$ \\
2 & Kuta & 8 siswa & $95 \mathrm{kk}$ \\
3 & Kuta Utara & 59 siswa & $592 \mathrm{kk}$ \\
\hline
\end{tabular}

Sumber: Data PPLS 2015

Berdasarkan Tabel 2 didapatkan sebaran rumah tangga miskin di Kabupaten Badung Selatan terbesar pada penyebarannya di wilayah Kecamatan Kuta Utara, Kuta Selatan dan paling rendah di Kecamatan Kuta. Sedangkan dilihat dari kecenderungan anak-anak putus sekolah, ternyata sangat proporsional dengan jumlah rumah tangga miskin di tiga wilayah kecamatan di Badung Selatan tersebut.

Tabel 3

Jumlah Siswa Putus Sekolah dan Rumah Tangga Miskin Badung Utara

\begin{tabular}{clcc}
\hline No. & Kecamatan & Putus Sekolah & Rumah Tangga Miskin \\
\hline 1 & Mengwi & 328 siswa & $4129 \mathrm{kk}$ \\
2 & Abiansemal & 304 siswa & $4298 \mathrm{kk}$ \\
3 & Petang & 205 siswa & $2596 \mathrm{kk}$ \\
\hline
\end{tabular}

Sumber : Data PPLS 2015 
Berbeda dengan kondisi di wilayah Badung Selatan, maka wilayah Badung Utara dengan tiga kecamatan yaitu Kecamatan Petang, Kecamatan Abiansemal dan Kecamatan Mengwi ternyata merupakan wilayah dengan rumah tangga miskin yang jauh lebih besar dibandingkan dengan Wilayah Badung Selatan. Berdasarkan Tabel 1.3 ternyata rumah tangga miskin di Kecamatan Mengwi sebedar 4.129 kk, Kecamatan Abiansemal sebanyak 4.298 kk, serta Kecamatan Petang memiliki rumah tangga miskin sebanyak 2.596 kk. Dibandingian dengan wilayah Badung Selatan, maka sebaran rumah tangga miskin terbanyak berada di wilayah Badung Utara.

Berdasarkan jumah rumah tangga miskin, wilayah Kecamatan Abiansemal memiliki jumlah $4.298 \mathrm{kk}$ yang masih lebih besar dibandingkan dengan Kecamatan Mengwi, tetapi dilihat dari jumlah sebaran anak-anak putus sekolah, justru Kecamatan Mengwi tercatat memiliki angka putus sekolah lebih banyak yaitu 328 siswa berbading dengan 304 siswa, sehingga fakta demikian menunjukkan pola karakter kemiskinan di wilayah Kecamatan Mengwi tampak menjadi lebih komplek.

\section{Rumusan Pokok Masalah}

1. Bagaimana pengaruh Modal Sosial dan Kebijakan Pemerintah terhadap Kinerja Sosial Ekonomi Lembaga Perkreditan Desa

2. Bagaimana pengaruh Modal Sosial, Kebijakan Pemerintah, Kinerja Sosial Ekonomi Lembaga Perkreditan Desa terhadap Kesejahteraan Rumah Tangga Miskin 
3. Bagaimana Pengaruh Tidak Langsung Modal Sosial Dan Kebijakan Pemerintah terhadap Kesejahteraan Rumah Tangga Miskin melalui Kinerja Sosial Ekonomi Lembaga Perkreditan Desa

\section{Kesejahteraan Masyarakat}

Konsep kesejahteraan dikembangkan menjadi lebih luas dibandingan sekedar mengukur aspek pendapatan nominal. Kesejahteraan adalah standard living, wellbeing, welfare, dan quality of life. Brudeseth (2015) menyatakan kesejahteraan sebagai kualitas kepuasan hidup yang bertujuan untuk mengukur posisi anggota masyarakat dalam membangun keseimbangan hidup mencakup antara lain, (a) kesejahteraan materi, (b) kesejahteraan bermasyarakat, (c) kesejahteraan emosi, (d) keamanan.

Kajian organisasi ekonomi dalam keluarga menggunakan permintaan terhadap barang strategis sebagai indikator kesejahteraan. Ukuran lainnya kesejahteraan adalah proporsi pengeluaran untuk pangan. Kesejahteraan merupakan pencerminan dari kualitas hidup manusia (quality of human life), yaitu suatu keadaan ketika terpenuhinya kebutuhan dasar serta terealisasikannya nilai-nilai hidup. Istilah kesehatan sosial keluarga dan kesejahteraan sosial keluarga bagi keluarga yang dapat melahirkan individu dengan pertumbuhan dan perkembangan yang baik.

\section{Pola Karakteristik Rumah Tangga Miskin}

Pola kemiskinan dapat dilihat berdasarkan pengukuran dimensi ekonomi mencakup kemampuan konsumsi dari rumah tangga dalam mencukupi kebutuhannya. World Bank mengukur dua dimensi pola kemiskinan penduduk. 
Kelompok pertama, adalah rumah tangga sangat miskin yang memilki pendapatan kurang dari US 1.25 untuk mencukupi kebutuhan konsumsi dalam sehari, serta kelompok miskin yaitu pemegang pendapatan kurang dari \$2 untuk memenuhi kebutuhan dalam sehari (Banerjee dan Duflo, 2007). Akibat dari keterbatasan kemampuan pendapatan untuk mendapatkan pola konsumsi yang layak, maka pada warga miskin menghadapi resiko tidak tercukupinya kebutuhan nutrisi yang dapat menyebabkan peluang untuk membangun perbaikan pedapatan dan mendapatkan segmen pasar menjadi lebih terbatas (Chakravarti, 2006).

Gambaran tentang rumah tangga miskin lebih dipertajam sebagai fenomena yang bersifat multi dimensi dan kompleksitas sosial ekonomi (Arora and Romijn, 2012), yang memerlukan sejumlah pendekatan ekonomi dan sosial dalam memahami persoalan kemiskinan. Banjere dan Duflo (2007) merumuskan pola karakteristik kemiskinan sebagai kompleksitas dari persoalan sosial ekonomi, politik kelembagaan, serta budaya kemasyarakatan yang berproses, dimana terdapat sejumlah kelompok dalam berbagai sebab tertentu tidak memiliki kemampuan untuk membangun kesejahteraan. Aspek terpenting yang banyak dillihat sebagai bagian penting dari aspek kemiskinan adalah vulnerability. World Bank (2015) mendefinisikan vulnerability sebagai peluang terjadinya resiko bahwa kemiskinan yang dihadapi oleh kelompok rumah tangga miskin dapat menjadi lebih miskin pada hari berikutnya, disebabkan oleh keterbatasan kemampuan konsumsi yang berdampak kepada tidak terpenuhinya nutrisi untuk mempu mempertahankan kondisi fisik secara normal dalam membangun kinerja pasar. Itu sebabnya dalam berbagai aktivitas pemberdayaan penurunan jumlah 
rumah tangga miskin dari program bantuan World Bank selalu memmberikan perhatian terhadap aspek vulnerability sebagai fokus strategi dalam menurunkan rumah tangga miskin di berbagai negara berkembang.

\section{Modal Sosial dan Kemiskinan}

Pendekatan konsep untuk membangun penguatan ekonomi rumah tangga miskin menjadi lebih terbatas apabila dikaitkan dengan potensi asset yang mereka miliki, sehingga muncul kemudian pandangan bahwa modal sosial dapat menjadi kekuatan dalam rangka menurunkan resiko vulnerability dan dapat mewujudkan sumber pendapatan yang lebih stabil dimasa depan. Scott (1976) mendapatkan sejumlah fakta bahwa wilayah pedesaan dengan latar belakang sektor agraris adalah didominasi oleh pola karakteristik produksi yang masih bersifat subsistence sehingga memiliki sikap budaya norma kebersamaan, sharing community yang kuat, sehingga dapat menjadi kekuatan dalam rangka meningkatkan posisi kekuatan rumah tangga miskin dalam membangun jaringan pasar, mendapatkan akses layanan keuangan dan layanan pendidikan dan pelatihan.

Putnam (1993) mengembangkan teori jaringan, kebersamaan norma dan kepercayaan sebagai kekuatan modal sosial yang dapat berfungsi membangun produktivitas produksi dan perluasan segmentasi peluang pasar. Hasil penelitian empirik menunjukkan bahwa modal sosial dapat berfungsi menjadi kekuatan dalam menurunkan rumah tangga miskin (Woolcock and Narayan, 2000).

\section{Kinerja Lembaga Keuangan}


Kinerja keuangan lembaga keuangan mikro tidak dapat disamakan dengan lembaga keuangan bank komersial yang sepenuhnya digerakkan untuk mencapai pertumbuhan laba sesuai dengan keinginan pemegang saham dari perbankan tersebut. Pada lembaga keuangan mikro, target kinerja yang dicapai memiliki dua target secara bersamaan, yaitu target usaha pertumbuhan laba usaha dan target mewujudkan kesejahteraan sosial.

Kinerja usaha jasa keuangan lembaga keuangan mikro berbeda dengan pengukuran kinerja keuangan bank komersial, disebabkan oleh peran lembaga keuangan mikro yang berfungsi ganda, sebagai lembaga keuangan yang mencari laba dan sebagai lembaga keuangan yang menargetkan tercapainya tujuan sosial tertentu, seperti upaya untuk mengurangi rumah tangga miskin, perluasan akses keuangan untuk kelompok masyarakat berpendapatan kebawah.

\section{METODE PENELITIAN}

Metode penelitian yang digunakan dalam penelitian ini adalah kuantitatif, menggunakan data primer yang diperoleh dari responden menggunakan kuisioner. Populasi merupakan rumah tangga miskin yang yang terdapat di Kabupaten Badung tahun 2015. Lokasi penelitian ini adalah Kecamatan Mengwi, Kabupaten Badung, dipilih sebagai pusat kegiatan pariwisata internasional. Fokus kegiatan penelitian ini adalah studi tentang peranan Lembaga Perkreditan Desa (LPD) dalam rangka menurunkan jumlah rumah tangga miskin di Kabupaten Badung. Berdasarkan data yang tersedia dari penyebaran rumah tangga miskin di Kabupaten Badung, Jumlah rumah tangga miskin di Kecamatan Mengwi 
sebanyak 4.129 kk dengan jumlah anak putus sekolah sebanyak 328 siswa (PPLS, 2015).

Dalam penelitian ini terdapat 2 variabel bebas (independen variable) yaitu modal sosial, kebijakan pemerintah, sebuah variable terikat (dependen variable) yaitu kesejahteraan rumah tangga miskin serta sebuah variable perantara (intervening variable) yaitu kinerja sosial ekonomi lembaga perkreditan desa. Definisi operasional masing-masing variabel yang diteliti adalah sebagai berikut:

1. Modal sosial merupakan asset non fisik yang memiliki kekuatan dalam membangun kinerja produk dan peluang kesempatan kerja. Dengan indikator yaitu, kepercayaan, norma - norma, dan jaringan

2. Kebijakan pemerintah merupakan konstruk yang dibangun berdasarkan persepsi masyarakat sebagai pengguna jasa pelayanan pemerintahan. yaitu kebijakan pemerintah berkaitan dengan pemberdayaan, pendampingan, bantuan kesejahtaan dan pengembangan kesejahteraan masyarakat

3. Kinerja sosial ekonomi lembaga perkreditan desa adalah peranan LPD dalam meningkatkan kesejahtraan rumah tangga miskin. Variabel ini diukur dengan indikator sebagai berikut : Elibility, Affordability, Debt phobia, Complacency

4. Kesejahteraan masyarakat adalah kualitas hidup rumah tangga miskin di Kecamatan Mengwi. Variabel ini diukur dengan indikator sebagai berikut : kesehatan, peningkatan aset, pendidikan, dan pendapatan

Model dapat dilihat pada gambar 1 . 
Gambar 1

Kerangka Konsep Penelitian

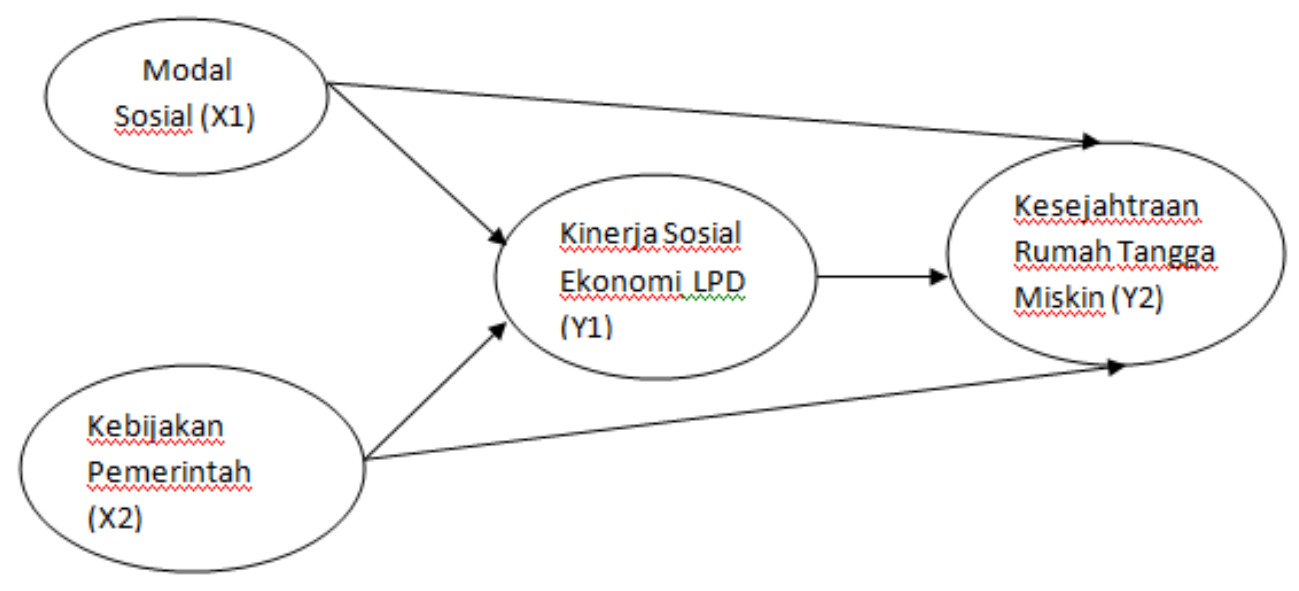

Pemerintah dengan salah satu fungsi utamanya sebagai pengalokasi melalui peningkatan pengeluaran pemerintah atau belanja pemerintah dapat menciptakan pertumbuhan ekonomi dengan penyediaan barang publik yang merupakan hal penting guna mencapai kesejahteraan masyarakat (Siregar dan Faizah, 2014).

Konsep modal sosial yang digagas oleh Putnam (1993) meliputi komponen kepercayaan, jaringan dan norma telah dijadikan sebagai instrumen untuk mengurangi rumah tangga miskin, antara lain melalui pemberdayaan yang dilakukan oleh Word Bank (1990) di Indonesia dan sejumlah negara lainnya. Kajian Cecci et al. (2010) membuktikan bahwa peran modal sosial memberikan konstribusi yang signifikan dalam mengurangi jumlah rumah tanggai miskin di pedesaan India

Grootaert (2001) membuktikan secara empiris bahwa penguatan modal sosial rumah tangga miskin menjadi kekuatan dalam percepatan rumah tangga miskin keluar dari lingkaran hidup miskin. Bahwa sebagaimana dinyatakan Ansari 
et al. (2012), resiko financial atas pinjaman perbankan yang menyebabkan rumah tangga miskin tidak dapat melaksanakan kewajibannya, dapat ditanggulnagi secara lebih mudah melalui jaringan modal sosial yang kuat dalam kelompok rumah tanggai miskin. Bahwa pengembangan model sosial menjadi relatif penting berkaitan dengan konsep kepercayaan, norma dan jaringan sebagaimana digagas oleh Putnam (1993), serta dukungan bukti empirik oleh Cecci et al. (2010) serta Grooteart (2001) dapat memberikan keyakinan bahwa penguatan modal sosial pada rumah tangga miskin dapat mengurangi resiko kegagalan kredit lembaga keuangan mikro.

Data yang telah terkumpul akan diolah dengan menggunakan teknik analisis statitistik deskriptif dan teknik analisis persamaan struktural (SEM) dengan alternatif Partial Least Square (PLS) (component based SEM). Terakhir, dilakukan interpretasi masing-masing variabel untuk melihat kesesuaian model teoritik dan empirik sehingga dapat ditarik kesimpulan dari rumusan masalah penelitian.

\section{HASIL DAN PEMBAHASAN}

\subsection{Deskripsi Variabel Penelitian}

Deskripsi variabel penelitian dijelaskan dengan tujuan untuk menunjukkan hasil yang diperoleh peneliti setelah menyebarkan kuisioner yang kemudian ditabulasi berdasarkan jawaban responden terhadap masing-masing indikator pengukur variabel. Deskripsi data penelitian menyajikan penilaian responden untuk setiap butir-butir pertanyaan yang diajukan dalam kuesioner penilaian responden dasajikan menurut variabel. Variabel-variabel yang dioperasionalkan 
dalam penelitian ini adalah Modal Sosial (X1), kebijakan pemerintah (X2), kinerja sosial ekonomi lembaga pereditan desa (Y1), dan kesejahteraan rumah tangga miskin (Y2) dengan mengunakan skala pengukuran 1 sampai 5. Untuk mendeskripsikan penilaian rata-rata responden mengenai variabel-variabel dalam penelitian, hasil jawaban responden disesuaikan dengan desain skala pengukuran yang telah ditetapkan kemudian diformulasikan ke dalam beberapa interval kelas (Suharsono, 2010:21).

Tabel 5.5

Distribusi Frekwensi Jawaban Responden

\begin{tabular}{|c|c|c|c|c|}
\hline No & Variabel & Indikator & Simbol & $\begin{array}{l}\text { Skor } \\
\text { Rerata }\end{array}$ \\
\hline \multirow[t]{4}{*}{1} & Modal Sosial & 1. Jaringan & $\mathrm{X} 1.1$ & 3.42 \\
\hline & $(\mathrm{X} 1)$ & 2. Kepercayaan & $\mathrm{X} 1.2$ & 3.37 \\
\hline & & 3. Norma & $\mathrm{X} 1.3$ & 3.3 \\
\hline & & Rerata Modal Sosial & $\mathrm{X} 1$ & 3.36 \\
\hline \multirow[t]{6}{*}{2} & Kebijakan & 1. Bantuan & $\mathrm{X} 2.1$ & 3.4 \\
\hline & Pemerintah & 2. Pemberdayaant & $\mathrm{X} 2.2$ & 3.45 \\
\hline & $(\mathrm{X} 2)$ & 3. Pendampingan & $\mathrm{X} 2.3$ & 3.22 \\
\hline & & 4. Peluang Kerja & $\mathrm{X} 2.4$ & 3.6 \\
\hline & & Rerata Kebijakan & $\mathrm{X} 2$ & 3.4 \\
\hline & & Pemerintah & & \\
\hline \multirow[t]{5}{*}{3} & Kinerja sosial & 1. Elibility & Y1.1 & 3.53 \\
\hline & ekonomi lembaga & 2. Affordability & Y1.2 & 3.27 \\
\hline & perkreditan desa & 3. Debt phobia & Y1.3 & 3.3 \\
\hline & (Y1) & 4. Complacency & Y1.4 & 3.3 \\
\hline & & $\begin{array}{l}\text { Rerata Kinerja sosial ekonomi lembaga } \\
\text { perkreditan desa }\end{array}$ & Y1 & 3.35 \\
\hline \multirow[t]{7}{*}{4} & Kesejahteraan & 1. Pendapatan & Y2.1 & 3.35 \\
\hline & Rumah tangga & 2. Peningkatn aset & Y 2.2 & 3.25 \\
\hline & miskin & 3. Pendidikan & Y2.3 & 3.43 \\
\hline & $(\mathrm{Y} 2)$ & 4. Kesehatan & Y2.4 & 3.4 \\
\hline & & 5. Persiapan Hari Tua & Y2.5 & 3.33 \\
\hline & & Rerata & $\mathrm{Y} 2$ & 3.35 \\
\hline & & Kesejahteraan rumah tangga miskin & & \\
\hline
\end{tabular}

Sumber: Hasil penelitian, 2017 (diolah)

Berdasarkan data hasil analisis deskritif di atas, maka rincian distribusi frekuensi jawaban responden dapat dijelaskan sebagai berikut: 
1) Variabel Modal Sosial (X1) dibentuk oleh 4 indikator dengan 4 butir pertanyaan yang diukur dengan skala rating 1-5. Jawaban responden secara keseluruhan terhadap indikator modal sosial jika dilihat dari rerata sebesar 3,36, sehingga dikategorikan cukup baik. Sementara, rincian masing-masing indikator modal sosial (X1) yakni, kepercayaan (X1.1) dengan nilai rerata 3,42 yang berarti adanya tingkat kepercayaan antar masyarakat yang baik. Indikator Jaringan (X1.2) dengan rerata 3,37 yaitu termasuk kategori cukup baik dalam hal membangun jaringan informasi dalam meningkatkan pendapatan. Indikator norma (X1.3) rerata 3,3 dengan kategori cukup baik.

2) Variabel Kebijakan Pemerintah (X2) dibentuk oleh 4 indikator dengan 4 butir pertanyaan yang diukur dengan skala rating 1-5. Jawaban responden secara keseluruhan terhadap indikator Kebijakan pemerintah (X2) jika dilihat dari rerata sebesar 3,4, sehingga dikategorikan baik. Sementara, rincian masingmasing indikator kebijakan pemerintah (X2) yakni, indikator Bantuan (X2.1) dengan nilai rerata 3,4 yang berarti sudah baik, pemberdayaan (X2.2) dengan rerata 3,45 yaitu termasuk kategori baik, indikator pendampingan (X2.3) rerata 3,22 dengan kategori cukup baik, dan indikator peluang kerja (X2.4) rerata 3,6 dengan kategori baik.

3) Variabel Kinerja sosial ekonomi lembaga perkreditan desa (Y1) dibentuk oleh 4 indikator dengan 4 butir pertanyaan yang diukur dengan skala ranting 1-5. Jawaban responden secara keseluruhan terhadap indikator Kinerja sosial ekonomi lembaga perkreditan desa (Y1) jika dilihat dari rerata sebesar 3,35, sehingga dikategorikan cukup baik. Sementara, rincian masing-masing 
indikator Kinerja sosial ekonomi lembaga perkreditan desa (Y1) yakni, indikator Elibility (Y1.1) dengan nilai rerata 3.53 yang berarti memberikan dampak positif, Affordability (Y1.2) dengan rerata 3.27 yaitu termasuk kategori baik, indikator Debt phobia (Y1.3) rerata 3.3 dengan kategori baik, indikator Complacency (Y1.4) rerata 3.3 dengan kategori baik.

4) Variabel kesejahteraan rumah tangga miskin (Y2) dibentuk oleh 5 indikator dengan 5 butir pertanyaan yang diukur dengan skala ranting 1-5. Jawaban responden secara keseluruhan terhadap indikator kesejahteraan rumah tangga miskin (Y2) jika dilihat dari rerata sebesar 3,35 sehingga dikategorikan baik. Sementara, rincian masing-masing indikator kesejahteraan rumah tangga miskin (Y2) yakni, indikator Pendapatan (Y2.1) dengan nilai rerata 3.35 yang berarti masuk dalam kategori baik, indikator Peningkatn aset (Y2.2) dengan rerata 3.25 yaitu termasuk kategori baik dan lancar, indikator pendidikan (Y2.3) rerata 3.43 dengan kategori memiliki kesadaran yang tinggi, indikator Kesehatan (Y2.3) rerata 3.4 dengan kategori memiliki kesadaran yang tinggi, indicator Persiapan Hari Tua (Y2.4) dengan rerata 3.33 yang berarti baik.

Pengujian tingkat reliabilitas instrument penelitian dilakukan dengan prosedur cronbach, sedangkan untuk melalukan uji terhadap validitas instrument dilakukan dengan mempergunakan prosedur uji KMO, kedua metode pengujian tersebut diperoleh melalui bantuan paket Soaftware SPSS. Hasil pengolahan data untuk uji reliabotas dan uji validitas disajikan pada Tabel 5.2.

Tabel 4 
Hasil Uji Instrumen Penelitian

Reliabilitas dan Validitas Untuk 41 Responden

\begin{tabular}{crcrl}
\hline Dimensi & $\begin{array}{c}\text { Cronbach's } \\
\text { Alpha }\end{array}$ & Ket. & $\begin{array}{l}\text { Nilai } \\
\text { KMO } \\
\text { MSA }\end{array}$ & Ket. \\
\hline X1 & 0.779 & Realiabel & 0.709 & Valid. \\
X2 & 0.935 & Realiabel & 0.830 & Valid. \\
Y1 & 0.834 & Realiabel & 0.773 & Valid. \\
Y2 & 0.913 & Realiabel & 0.854 & Valid. \\
\hline
\end{tabular}

Sumber: Hasil Penelitian

Penelitian ini mempergunakan uji statistik cronbach Alpha yaitu untuk melihat konsistensi internal dengan upaya melakukan pengujian untuk mendapatkan penilaian atas kondisi inter-item correlation dari indikator yang merefleksikan bahwa konstruk telah memiliki sebaran nilai yang konsisten dinyatakan sebagai reliabilitas instrumen apabila nilai cronbach alpha adalah minimal 0.70. Berdasarkan sebaran nilai cronbach alpha diatas 0.70 , sehingga semua konstruk yang disertakan pada penelitian ini dinyatakan reliable.

Penelitian ini mempergunakan software SmartPls versi 3.2.6 sebagai pendukung untuk mendapatkan hasil analisis outer-model untuk mengukur pada tingkat pertama posisi relasi antara konstruk dengan indikatornya. Pengujian tahap pertama, adalah untuk mengevaluasi tingkat reliabilitas instrumen penelitian berdasarkan tiga prosedur pengujian yaitu (a) cronbach Alpha, (b) composite reliability serta (d) convergence validity melalui sebaran nilai AVE. Ketiga komponen pengujian disajikan pada table 5 . 
Tabel 5

Hasil Uji Reliabilitas Penelitian

\begin{tabular}{llrr}
\hline & \multicolumn{2}{l}{ Cronbach } & \\
Alpha & \multicolumn{1}{c}{ C.A } & AVE \\
\hline X1 & 0.974 & 0.974 & 0.926 \\
X2 & 0.969 & 0.969 & 0.885 \\
Y1 & 0.970 & 0.970 & 0.890 \\
Y2 & 0.970 & 0.970 & 0.867 \\
\hline
\end{tabular}

Sumber : Hasil Penelitian

Berdasarkan Tabel 5 didapatkan sebaran nilai cronbach Alpha diatas 0.70 untuk semua konstruk penelitian ini. Hair et al (2010) menyatakan bahwa nilai cronbach Alpha diatas 0.70 adalah memilki syarat sebagai konstruk penelitian yang reliable. sehingga dapat disimpulkan bahwa semua instrumen yang dipergunakan penelitian ini adalah reliable.

Menganalisis secara terpisah kedua variabel dependen itu diperlukan untuk memastikan peran yang ditunjukkan oleh variable dependent berikutnya, selain dari variable dependent dari persamaan awal. Hal ini dilakukan untuk melakukan evaluasi apakah terdapat peluang dependent variable berikutnya dalam memperjelas model penelitian menjadi lebih kuat, memadai atau lemah (Cohen, 1988).

Berdasarkan Tabel 5.5 dapat dinyatakan bahwa dependent variable kinerja sosial ekonomi lembaga perkreditan desa $(\mathrm{Y} 1)$ dengan nilai $\mathrm{R}^{2}=0.908$, serta konstruk kesejahteraan rumah tangga miskin sebagai variable dependen (Y2), dengan nilai $\mathrm{R}^{2}=0.957$ tercatat lebih tinggi dibandingkan dependent variable kinerja sosial ekonomi lembaga keuangan micro (Y1). Jika dibandingkan dengan sebaran nilai $\mathrm{R}^{2}$ dan $\mathrm{R}^{2}$ Adjusted, maka tampak bahwa sebaran nilai $\mathrm{R}^{2}$ dari $\mathrm{Y} 1$ 
dan Y2 masih lebih besar dibandingkan dengan sebaran nilai $\mathrm{R}^{2}$ Adjusted untuk dua konstruk bersangkutan.

Tabel 6

Sebaran Nilai $\mathrm{R}^{2}$ dan $\mathrm{R}^{2}$ adjusted

\begin{tabular}{ccr}
\hline & R Square & \multicolumn{2}{c}{$\begin{array}{l}\text { R Square } \\
\text { Adjusted }\end{array}$} \\
\hline Y1 & 0.908 & 0.903 \\
Y2 & 0.957 & 0.953 \\
\hline \multicolumn{2}{l}{ Sumber: data penelitian }
\end{tabular}

Tabel 6 juga menyertakan nilai $\mathrm{R}^{2}$ adjusted, yang ternyata penyebarannya masih lebih rendah dari $\mathrm{R}^{2}$, sehingga dapat disimpulkan bahwa penambahan konstruk masih dimungkinkan dimasa depan.

Berdasarkan Tabel 7, ternyata didapatkan dari sebanyak lima tujuan penelitian yang disusun sebaga relasi direct effect, didapatkan sebanyak satu hipotesis yang tidak signifikan dengan P-value lebih besar dari 5 persen

Tabel 7

Hasil Analisis Path Coefficient Dan Signifikasi

\begin{tabular}{|c|c|c|c|c|c|c|}
\hline & $\begin{array}{l}\text { Original } \\
\text { Sample } \\
\text { (O) }\end{array}$ & $\begin{array}{l}\text { Sample } \\
\text { Mean } \\
\text { (M) }\end{array}$ & $\begin{array}{l}\text { Standr } \\
\text { Error }\end{array}$ & $\begin{array}{c}\mathbf{T} \\
\text { Stats }\end{array}$ & $\begin{array}{c}\mathbf{P} \\
\text { Values }\end{array}$ & KET. \\
\hline X1 -> Y1 & 0.516 & 0.547 & 0.239 & 2.161 & 0.031 & $\begin{array}{l}\text { Signifikan } \\
\text { Tdk }\end{array}$ \\
\hline X1 -> Y2 & -0.073 & -0.067 & 0.144 & 0.506 & 0.613 & Signif. \\
\hline X2 -> Y1 & 0.474 & 0.446 & 0.227 & 2.087 & 0.037 & Signifikan \\
\hline $\mathrm{X} 2$-> Y2 & 0.527 & 0.501 & 0.196 & 2.697 & 0.007 & Signifikan \\
\hline Y1 -> Y2 & 0.539 & 0.561 & 0.182 & 2.957 & 0.003 & Signifikan \\
\hline
\end{tabular}

Penelusuran terhadap peran mediasi ternyata menunjukkan relasi yang signifikan, yaitu hubungan tidak langsung dari modal sosial (X1) terhadap 
kesejahteraan rumah tangga miskin (Y2) melalui kinerja sosial ekonomi lembaga perkreditan desa (Y1) adalah signifikan, hal yang juga searah didapatkan pada relasi mediasi dari kebijakan pemorintah (X2) yang berpengaruh secara tidak langsung terhadap kesejahrteraan rumah tangga miskin (Y2) melalui kinerja sosial ekonoi lembaga perkreditan desa (Y1) adalah signifikan. (lihat Tabel 8).

Tabel 8

Hasil Analisis Signifikansi Indirect Effect Modal Sosial (X1) dan Kebijakan Pemerintah (X2) Melalui Kinerja Sosial Ekonomi Lembaga Perkreditan Desa

\begin{tabular}{|c|c|c|c|c|c|c|}
\hline & $\begin{array}{l}\text { Original } \\
\text { Sample } \\
(\mathbf{O}) \\
\end{array}$ & $\begin{array}{l}\text { Sample } \\
\text { Mean } \\
(\mathrm{M}) \\
\end{array}$ & $\begin{array}{l}\text { Standrs } \\
\text { Error }\end{array}$ & $\begin{array}{c}\mathbf{T} \\
\text { Stats }\end{array}$ & $\begin{array}{c}\mathbf{P} \\
\text { Values } \\
\end{array}$ & KET \\
\hline X1 -> Y2 & 0.279 & 0.306 & 0.081 & 3.444 & 0.0006 & Signif. \\
\hline $\mathrm{X} 2$-> Y2 & 0.256 & 0.251 & 0.091 & 2.813 & 0.0026 & Signif. \\
\hline
\end{tabular}

Sumber : Data Penelitian

Berdasarkan Tabel 7 dan 8 maka dapat diinterprestasikan hasil analisis sebagai berikut:

1. Besarnya estimasi dari modal sosial (X1) terhadap kinerja sosial ekonomi lembaga perkreditan desa (Y1) adalah 0.516. Koefisien tersebut bertanda positif yang apabila modal sosial semakin ditingkatkan maka semakin besar pula kinerja sosial ekonomi lembaga perkreditan desa (Y1). Dan sebaliknya semakin rendah modal sosial maka semakin rendah pula kinerja sosial ekonomi lembaga perkreditan desa (Y1).

Hal ini sejalan dengan penelitian yang dilakukan oleh Erwin Thobias (2013) dimana modal sosial berpengaruh positif terhadap perkembangan usaha 
mikro kecil menengah di Kecamatan Kabaruan Kabupaten Kepulauan Talaud.

2. Besarnya koesifien estimate dari kebijakan pemerintah (X2) terhadap kinerja sosial ekonomi lembaga perkreditan desa (Y1) adalah 0.474. Koefisien tersebut bertanda positif yang apabila kebijakan pemerintah (X2) semakin ditingkatkan maka semakin besar pula kinerja sosial ekonomi lembaga perkreditan desa (Y1)

Penelitian ini searah dengan Stiglitz (1996) yang mendapatkan fakta empirik bahwa kebijakan pemerintah sangat signifikan dalam mendorong peningkatan kinerja ekonomi dan sosial lembaga keuangan berskala kecil, termasuk Lembaga Keuangan Mikro.

3. Besarnya koesifien estimate dari kebijakan pemerintah (X2) terhadap kesejahteraan rumah tangga miskin (Y2) adalah 0.527. Koefisien tersebut bertanda positif, sehingga dapat dinyatakan apabila kebijakan pemerintah (X2) semakin ditingkatkan maka semakin besar pula peluang peningkatan kesejahteraan rumah tangga miskin (Y2)

Hasil yang sama juga diperoleh oleh Agus Suryono, (2014). dimana kebijakan pemerintah yang terorganisasi dari pelayanan-pelayanan dan lembaga-lembaga sosial, yang dirancang untuk membantu dan mendorong individu-individu dan kelompok-kelompok dalam masyarakat dapat meningkatkan tingkat hidup dan kesehatan yang maksimal. Rachmat hendayana dan Sjahrul Bustaman (2007) mengemukakan Lembaga Keuangan Mikro masih dapat dijadikan sebagai salah satu instrument 
kebikajan pemerintah dalam upaya meningkatkan produktivitas pertanian dalam meningkatkan pendapatan dan kesejahtraan petani

4. Besarnya coefficient estimate dari kinerja sosial ekonomi lembaga perkreditan desa (Y1) terhadap kesejahteraan rumah tangga miskin (Y2) adalah 0.539. Koefisien tersebut bertanda positif yang apabila kinerja sosial ekonomi lembaga perkreditan desa (Y1) semakin ditingkatkan maka semakin besar pula tingkat kesejahteraan rumah tangga miskin (Y2). Sebaliknya semakin rendah kinerja sosial ekonomni lembaga perkreditan desa (Y1) maka semakin rendah pula tingkat kesejahteraan rumah tangga miskin (Y2).

Yopi Saleh dan Yayat Hidayat (2011), Pengembangan LKM dapat menjadi salah satu solusi efektif dalam pengentasan kemiskinan dengan bantuan peran dan intervensi dari berbagai pihak baik pemerintah, non-pemerintah serta masyarakat.

5. Penelusuran terhadap pengaruh tidak langsung dari modal sosial (X1) terhadap tingkt kesejahteraan rumnah tangga (Y2) melalui kinerja sosial ekonomi lembaga perkreditan desa (Y1) adalah signifikan berdasarkan tingkat kepercayaan $5 \%$, dengan nilai $\mathrm{t}=3.444$ yang ternyata masih lebih besar dibandingkan dengan tabel $\mathrm{t}=1.96$. Sehubungan dengan pengaruh langsung dari modal sosial terhadap kesejahteraan rumah tangga miskin adalah tidak signifikan, maka model relasi mediasi yang didapatkan adalah full mediation. 
6. Penelusuran terhadap pengaruh tidak langsung dari kebijakan pemerintah (X2) terhadap tingkat kesejahteraan (Y2) melalui kinerja sosial ekononi lembaga perkreditan desa (Y1) adalah signifikan berdasarkan tingkat kepercayaan $5 \%$, dengan nilai $t=2.813$ yang ternyata masih lebih besar dibandingkan dengan tabel $t=1.96$. Sehubungan dengan pengaruh langsung dari kebijakan pemerintah (X2) terhadap kesejahteraan rumah tangga miskin (Y2) adalah signifikan, maka model relasi mediasi yang didapatkan adalah partial mediation..

\section{KESIMPULAN DAN SARAN}

Bahwa keberadaan lembaga perkreditan desa (LPD) sebagai lembaga keuangan mikro telah mendapat respon positif dari partisipasi rumah tangga miskin sebagai lembaga yang telah memberikan penguatan pemodalan bagi rumah tangga miskin, sehingga perlu semakin ditingkatjan dimasa datang dalam rangka keikut-sertaan LPD dalam menurunkan angka kemiskinan di Kecamatan Mengwi Kabupaten Badung.

Bahwa ternyata kebijakan pemerintah terbukti dapat meningkatkan kesejahtraan rumah tangga miskin, searah dengan modal sosial rumah tangga miskin. Meskipun demkian, peran kebijakan pemerintah dalam penguatan kinerja sosial ekonomi lembaga keuangan mikro terbukti berpengaruh kuat dalam meningkatkan kesejahteraan rumah tangga miskin.

\section{REFRENSI}

ADB. 2003. Finance for the Poor: Microfinance Development Strategy. Manila. Asian Development Bank. 
Arora Saurabh and Romijin Henny. 2011. The empty rhetoric of poverty reduction at the base of the pyramid. Sage jurnal.

Banerjee Abhijit V. and Duflo Esther. 2007. The Economic Lives of the Poor. Journal of Economic Perspectieves

Bank Dunia. 2014. The Impact of Microcredit on the Poor in Bangladesh: Revisiting the Evidence"

Beck, T., Demirguc-Kunt, A., and Levine R., 2007. Finance, inequality and the poor. Journal of Economic Growth

Cécile, L. \& Manfred, Z.2010. Distribution, Growth, and Performance of Microfinance Institutions in Africa, Asia, and Latin America Discussion Paper BRIEFS 114

Defourny Jacques and Nyssens Marthe. 2010. Conceptions Of Social Enterprise And Social Entrepreneurship In Europe And The United States: Convergences Anddivergences. Journal of Social Entrepreneurship.

Erwin Thobias. 2013. Pengaruh Modal Sosial Terhadap Perilaku Kewirausahaan Pada Pelaku Usaha Mikro Kecil Menengah Di Kecamatan Kabaruan Kabupaten Kepulauan Talaud. Journal “ACTA DIURNA” Edisi April 2013

Hair, Joseph F.et al, 1998. Multivariate Data Analysis . New Jersey: PrenticeHall, Inc

Kaplan dan Norton (1992). The Balanced Scorecard-Measures That Drive Performance. Harvad Business Review Januari-February 1992

Kipesha Erasmus Fabian (2013) Performance of Microfinance Institutions in Tanzania: Integrating Financial and Non financial Metrics European Journal of Business and Management. 2013

Khandker, S. 1998. Fighting Poverty with Microcredit: Experience from Bangladesh. New York: Oxford University Press.

Putnam RD (1993) The prosperous community: Social capital and public life. The American Prospect

Reed, L. (2015), State of the Microcredit Summit Campaign Report 2015, Washington D.C.:Microcredit Summit. 
Meyer, R. 2002. Track Record of Financial Institutions Assisting the Poor in Asia. ADB InstituteResearch Paper No. 49. ADB.

Montgomery, H. 2005. Serving the Poorest of the Poor: The Poverty Impact of the KhushhaliBank's Microfinance Lending in Pakistan. ADB Institute.

North D. 1990. Institutions, Institutional Change and Economic Performance. Cambridge: Cambridge University Press

Satya R. Cakravarti and Conchita D' Ambrosio. 2006. The Measurement of Social Exclusion. Review of Income and Wealth series 52

World Bank ( Word Bank, 2015) Overview Human decision making and development policy. World Bank Report.

Woolcock Michael and Narayan Deepa. 2000. Social Capital: Implications for Development Theory, Research, and Policy. The World Bank Research Observe. 